\title{
ANALISIS FORECASTING DEMAND DENGAN METODE LINEAR EXPONENTIAL SMOOTHING (STUDI PADA PRODUK BATIK FENDY, KLATEN)
}

\author{
Nita Kusumawardani, Muhammad Roestam Afandi, \& Lilia Pasca Riani \\ Universitas Negeri Yogyakarta, Indonesia \\ nitawardani@uny.ac.id,mroestamafandi@uny.ac.id,lilia.pasca.riani@uny.ac.id
}

\begin{abstract}
Abstrak: Tujuan dari penelitian ini adalah untuk mengevaluasi tingkat akurasi peramalan permintaan Batik Fendy menggunakan teknik MAPE. Adapun jenis penelitian ini merupakan penelitian deskriptif kuantitatif, menggunakan data sekunder dari penjualan perusahaan Batik Fendy periode bulan November 2018 - Onkoter 2019. Terdapat 5 tahapan dalam analisis data, yaitu 1) mentabulasikan data penjualan dan data produksi batik Fendy, 2) mengevaluasi metode peramalan penjualan yang dilakukan oleh perusahaan Batik Fendy dengan teknik MAPE, 3) memproyeksikan nilai alpha dan beta sebagai dasar peramalan linear exponential smoothing, 4) melakukan peramalan permintaan Batik Fendy dengan metode Linear Exponential Smoothing, dan 5) melakukan evaluasi metode peramalan dengan teknik MAPE. Hasil penelitian ini adalah nilai MAPE dari peramalan permintaan yang dilakukan oeh perusahaan Batik Fendy adalah sebesar 17,5\%; angka ini menunjukkan tingkat persentase kesalahan paling tinggi pada varian Batik Sarimbit Lengan Panjang, kemudian dengan data penjualan varian ini dilakukan peramalan penjualan dengan metode Linear Exponential Smoothing dan diperoleh MAPE sebesar 9,21\%. Sehingga dapat disimpulkan bahwa penggunaan metode Linear Exponential Smoothing dalam memprediksi penjualan Batik Fendy varian Sarimbit Lengan Panjang lebih akurat.
\end{abstract}

Kata kunci: Peramalan Penjualan, Linear Exponential Smoothing, Mean Absolute Precentage Error

\section{Analysis Forecasting Demand Method of Linear Exponential Smoothing (Studies in Products Batik Fendy, Klaten)}

\begin{abstract}
The purpose of this study was to evaluate the accuracy of forecasting demand for Batik Fendy using MAPE techniques. The type of this research is a quantitative descriptive study, using secondary data from the sales of the company Batik Fendy in the period November 2018 - October 2019. There are five stages in data analysis, namely 1) tabulating sales data and production data of Fendy batik, 2) evaluating sales forecasting methods conducted by the Batik Fendy company with the MAPE technique, 3) projecting alpha and beta values as the basis for forecasting linear, exponential smoothing, 4) forecasting requests for Batik Fendy with the Linear Exponential Smoothing method, and 5) evaluating the forecasting method with the MAPE technique. The results of this study are the MAPE value of demand forecasts made by the Batik Fendy company is $17.5 \%$. This figure shows the highest percentage of error in the variant of the Sarimbit Long Sleeve Batik. With the sales data, this variant is forecasted by using the Linear Exponential Smoothing method and obtained a MAPE of 9.21\%. So it can be concluded that the use of the Linear Exponential Smoothing method in predicting sales of the Sarimbit Arm Long Variant Batik is accurate.

Keywords: Sales Forecasting, Linear Exponential Smoothing, Mean Absolute Percentage Error
\end{abstract}

\section{PENDAHULUAN}

Industri batik di Indonesia pada era disrubsi teknologi dan globalisasi modern ini mengalami turbulensi yang signifikan. Rantai nilai yang telah dibangun sejak lama beresilieensi sedemikian rupa agar tetap eksis seiring dengan perkembangan dan kebutuhan pasar yang berubah dengan cepat. Seringkali terjadi goncangan pada sistem konvensional produksi batik yang menyebabkan 
persaingan semakin ketat dalam memperebutkan pasar. Pengusaha batik yang mayoritas adalah usaha rumahan dengan sedikit tenaga kerja dan teknologi sederhana kewalahan dalam memenuhi pesanan konsumen yang mendadak datang dari berbagai wilayah yang belum terduga oleh pengusaha batik tersebut. Market place online yang baru-baru ini menjadi popular dimanfaatkan sedemikian rupa oleh para dropshiper untuk menghubungkan antara konsumen dan produkproduk batik yang diinginkannya. Hal inilah yang memunculkan permasalahan baru terkait jumlah produk yang harus disediakan oleh pengusaha batik agar tetap dapat memenuhi semua pesanan konsumen secara langsung melalui showroom maupun dropshipper nya.

Di kabupaten Klaten, kecamatan Kalikotes merupakan salah satu sentra industri batik. Perkembangan omset penjualan dari para pengusaha batik, baik berupa kain maupun pakaian jadi berbagai model kian hari kian meningkat, Batik Fendy sebagai salah satu usaha yang memproduksi kain dan pakaian jadi batik di kecamatan Kalikotes ini juga mengalami hal serupa. Berdiri sejak tahun 1992 oleh Bapak Haji Muhammad Waluyo, awalnya hanya membuat kain batik tulis dengan 3 orang Pengobeng, tahun 2019 ini sudah mempekerjakan lebih dari 100 orang, dengan varian kain dan pakaian jadi yang beragam. Jumlah produk yang dibuat juga semakin banyak dengan omset penjualan yang meningkat dari tahun ke tahun. Berikut adalah tabel peningkatan omset penjualan dan jumlah produksi batik di usaha batik Fendy:

\begin{tabular}{|c|c|c|c|}
\hline Tahun & Jumlah produksi & Omset Penjualan & $\begin{array}{c}\% \\
\text { Peningkatan }\end{array}$ \\
\hline 2013 & 5.135 & Rp 590.525.000 & - \\
\hline 2014 & 5.546 & Rp 637.790 .000 & 8.00 \\
\hline 2015 & 5.870 & $\operatorname{Rp} 675.050 .000$ & 5.84 \\
\hline 2016 & 6.150 & Rp 707.250.000 & 4.77 \\
\hline 2017 & 6.596 & Rp 758.540.000 & 7.25 \\
\hline 2018 & 6.825 & Rp 784.875.000 & 3.47 \\
\hline
\end{tabular}

Pada tabel 1 omset penjualan Batik Fendy dari tahun ke tahun terus mengalami peningkatan meskipun peningkatannya bersifat fluktuatif. Peningkatan paling sedikit adalah pada tahun 2017 ke tahun 2018 yang meningkat hanya 3,47\%, sedangkan prosentase terbesar ditunjukkan pada tahun 2013 ke tahun 2014 mengalami peningkatan sebesar 8\%.

Seiring dengan peningkatan jumlah produksi, batik Fendy juga terus mengusahakan perbaikan pada sistem produksinya, terkait dengan jumlah produk yang dibuat untuk masing-masing varian batik, baik kain batik dan pakaian jadi, usaha batik Fendy sering kali mengalami permasalahan kesalahan dalam memprediksi jumlah produk yang diproduksinya, sehingga mengalami penumpukan produk jadi di showroomnya. Beberapa varian batik pakaian jadi yang sedang diminati konsumen justru mengalami keterlambatan dalam pembuatan dan kehabisan persediaan, sedangkan varian-varian pakaian batik yang cenderung menurun peminatnya justru diproduksi dalam jumlah yang banyak, sehingga kesulitan dalam memasarkan. 


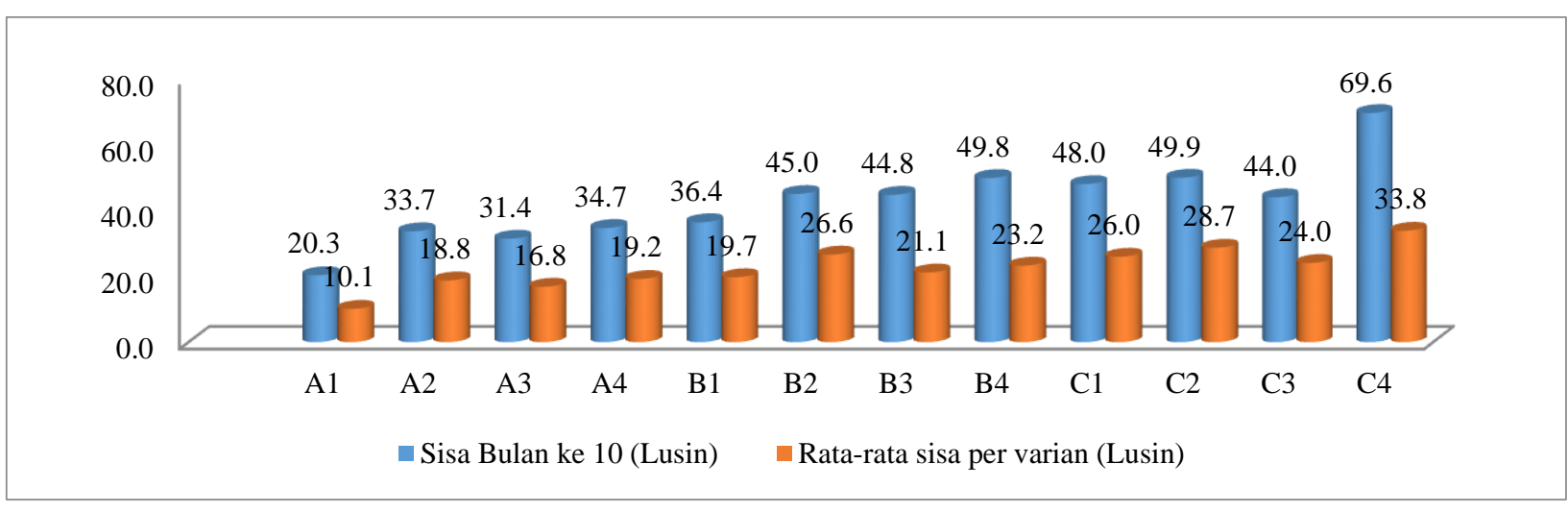

Gambar 1. Grafik jumlah pakaian yang tidak terjual bulan Oktober dan Rata-rata pakaian yang tidak terjual per varian dalam satuan Lusin

Dari gambar diatas, dapat diketahui bahwa untuk varian C4 (Sarimbit lengan panjang furing) menunjukkan angka sisa produk tertinggi yaitu 69,6 Lusin pada bulan Oktober yang akan membebani penjualan pada bulan Noveember 2019. Varian Sarimbit lengan panjang furing juga menunjukkan angka rata-rata produk yang tidak terjual paling banyak jika dibandingkan dengan varian lain. Hal ini menjadi permasalahan tersendiri pada Usaha Batik Fendy, karena jumlah produk yang tidak terjual akan membebani penjualan periode berikutnya.

Selama ini untuk memprediksi penjualan perbulannya, pemilik usaha batik Fendy melakukan peramalan permintaan berdasarkan intuisi atau kebiasaan saja, belum menerapkan metode tingkat lanjut jenis apapun. Berikut adalah jumlah produk yang terjual berdasarkan varian pakaian batik yang diproduksi oleh Batik Fendy selama periode bulan November 2018 - Oktober tahun 2019.

Berdasarkan uraian diatas, maka kebiasaan dalam memproduksi pakaian batik tanpa memprediksi dan meempertimbangkan pakaian yang tidak terjual pada periode sebelumnya dapat merugikan perusahaan, sehingga perlu dilakukan perubahan-perubahan untuk mengeliminasi pemborosan tersebut, salah satunya adalah dengan melakukan peramalan permintaan. Peramalan penjualan dapat dilakukan dengan metode-metode tertentu untuk memperoleh hasil yang akurat. Dalam penelitian ini, penulis menggunakan metode linear exponential smoothing sebagai metode peramalannya dan menggunakan alpha 0,8 untuk melihat fluktuasi data permintaan periode sebelumnya dan beta 0,1 untuk memprediksi kecenderungan data.

\section{METODE}

Penelitian ini merupakan penelitian deskriptif dengan pendekatan kuantitatif. Data yang dipakai dalam analisis adalah data sekunder berdasarkan catatan dari Usaha Batik Fendy, Klaten, yakni data penjualan produk batik setiap variannya pada bulan November 2018 hingga Oktober 2019. Teknik analisa data dilakukan dalam beberapa tahapan, yaitu: 1) Mengumpulkan data produksi dan data penjualan Batik Fendy periode November 2018 sampai Oktober 2019. Membuat grafik yang memperlihatkan distribusi data; 2) Menentukan efektifitas metode peramalan yang dilakukan oleh Batik Fendy dengan teknik MAPE; 3) Menentukan proyeksi data berupa $\alpha$, dan $\beta$; 4 ) Menghitung peramalan setiap periodenya dengan metode holt winter's linear exponential smoothing, dan 5) Menentukan efektivitas metode peramalan menggunakan teknik MAPE.

Menurut Maricar (2019:38) menyebutkan peramalan merupakan proses untuk memperkirakan besaran kebutuhan / kejadian yang terjadi dimasa mendatang. Kebutuhan ini meliputi dimensi kuantitas, kualitas, waktu, dan lokasi yang diperlukan untuk mencapai target yang telah 
ditetapkan. Menurut Yuniastari \& Wirawan (2016:98), peramalan merupakan suatu seni dari ilmu memprediksi sesuatu dimasa mendatang yang bertujuan untuk memperkirakan peristiwa-peristiwa yang akan terjadi dengan selalu memerlukan data-data dari masa lalu. Hal ini sejalan dengan pengertian konsep peramalan yang di kemukakan oleh Maricar (2019:39) bahwa peramalan merupakan suatu bidang ilmu yang digunakan sebagai alat untuk memprediksi sesuatu dengan dasar data yang ada sebelumnya dan diolah dengan cara tertentu.

Menurut Taylor \& Letham (2018:40) perusahaan lebih tertarik untuk melakukan peralaman dengan dasar data penjualan pada periode lalu, dengan asumsi bahwa apa yang terjadi di masa lalu akan terulang pada saat ini. Terdapat beberapa metode yang termasuk dalam analisis time series, yaitu Metode Rata-rata bergerak (Moving Average) kegiatan peramalan yang mengacu pada jumlah titik waktu tertentu yang bergerak secara sistematis, jumlah kegiatan selama titik waktu yang bersangkutan dibagi dengan jumlah titik waktu yang di maksud Land (2015:318). Metode Moving Average mempunyai karakteristik khusus yaitu: untuk menentukan ramalan pada periode yang akan datang memerlukan data historis selama jangka waktu tertentu. Misalnya, dengan 3 bulan moving average, maka ramalan bulan ke 5 baru dibuat setelah bulan ke 4 selesai/berakhir. Jika bulan moving averages bulan ke 7 baru bisa dibuat setelah bulan ke 6 berakhir. Semakin panjang jangka waktu moving average, efek pelicinan semakin terlihat dalam ramalan atau menghasilkan moving average yang semakin halus (Rachman, 2018:213). Persamaan Pada metode ini dipakai asumsi bahwa semua volume kegiayan yang dicakup mempunyai peluang yang sama untuk berulang. Rumus sederhana untuk menentukan peralaman dengan metode Moving Average adalah

$$
F_{n+1}=\frac{X_{1}+X_{2}+\cdots+X_{n}}{n}
$$

Dimana:

$$
\begin{aligned}
& \mathrm{F}_{\mathrm{n}+1}=\text { Peramalan periode } \mathrm{n}+1 \\
& \mathrm{n}=\text { Jumlah Periode }
\end{aligned}
$$

Pembobotan rata-rata bergerak (weighted moving average): metode peramalan volume kegiatan atau permintaan dimasa yang akan datang. Mengacu pada jumlah titik waktu yang bergerak secara sistematis dan probalitilas keberulangan kembali Land (2015:318). Rumus yang digunakan adalah

$$
F_{n+1}=\frac{\sum(\text { bobot periode } n)(\text { Permintaan dalam periode } n)}{\sum \text { bobot }}
$$

Menurut Heizer \& Render (2014) biasanya data pada periode terdekat diberikan bobot paling besar, asumsi ini muncul dengan dasar data pada periode paling dekat memiliki kemungkinan paling besar untuk terulang. Metode Exponential Smoothing adalah metode peramalan yang paling banyak digunakan. Perumusan metode peramalan eksponensial muncul pada 1950-an dari karya asli Brown \& Holt yang sedang bekerja pada pembuatan model peramalan untuk sistem kontrol ventura Yunika \& Sugiono (2017:60). Nilai alpha terletak antara 0 - 1, jika data aktual bersifat stabil maka nilai alpha mendekati 0 (nol), sebaliknya jika data aktual bersifat fluktuatif maka ditetapkan nilai alpha mendekati 1. Linear Exponential Smoothing Metode ini digunakan untuk serial data yang memiliki unsur tren atau kecenderungan yang bersifat konsisten. Kecenderungan ini disimbolkan dengan $\beta$ (beta). Rumus yang digunakan adalah:

$$
S_{t}=\alpha \cdot X_{t}+(1-\alpha)\left(S_{t-1}+T_{t-1)}\right)
$$




$$
\begin{gathered}
T_{t}=\beta \cdot\left(S_{t}-S_{t-1}\right)+(1-\beta) \cdot T_{t-1} \\
F_{t+m}=S_{t}+T_{t} \\
T_{1}=\frac{\left(X_{2}-X_{1}\right)-\left(X_{3}-X_{2}\right)-\left(X_{4}-X_{3}\right)}{3}
\end{gathered}
$$

Dimana:

$\mathrm{S}_{\mathrm{t}}=$ peramalan untuk unsur fluktuasi data

$\mathrm{T}_{\mathrm{t}}=$ peramalan untuk unsur kecenderungan data

$\mathrm{F}_{\mathrm{t}+\mathrm{m}}=$ peramalan periode $\mathrm{t}+\mathrm{m}$

$\mathrm{T}_{1}=$ kecenderungan data periode 1

Metode Asosiatif Metode ini biasanya dilakukan dengan menggunakan lebih dari satu variabel untuk memprediksi variabel lain, misal untuk memprediksi penjualan produk, digunakan variabel jumlah tenaga sales dan memperluas wilayah pemasaran produk tersebut. Metode ini umum disebut metode regresi linier. Teknik evaluasi peramalan ini dapat menggunakan MAD (Mean Absolut Deviation), MSE (Mean Squared Eror), dan MAPE (Mean Absolute Percent Error). Namun apabila unsur tersebut dihitung dalam satuan ribuan, maka nilai MAD dan MSE bisa menjadi sangat besar. Untuk menghindari masalah ini dapat menggunakan Mean Absolute Percent Error (MAPE) (Khamaludin, 2019:14) . MAPE dihitung dengan menentukan kesalahan absolut tiap periode dengan membagi nilai observasi pada periode tersebut kemudian di persentasekan. Metode ini memberikan petunjuk sebesara besar kesalahan peramalan dibanding dengan nilai sebenarnya.

$$
M A P E=\frac{\sum_{t=1}^{n} \frac{I Y_{t}-F_{t} I}{Y_{t}} \times 100}{n}
$$

Dimana:

$Y_{t}=$ Data Aktual periode $t$

$\mathrm{F}_{\mathrm{t}}=$ peramalan periode $\mathrm{t}$

$\mathrm{n}=$ banyaknya data

\section{HASIL DAN PEMBAHASAN}

Memprediksi penjualan produk yang terlalu besar dan kurang akurat dapat mengakibatkan biaya operasional meningkat sehingga modal yang dikeluarkan menjadi kurang efisien. Oleh karena itu, diperlukan suatu ilmu yang mampu memprediksi penjualan yang akan datang dengan melihat data dimasa lalu. 


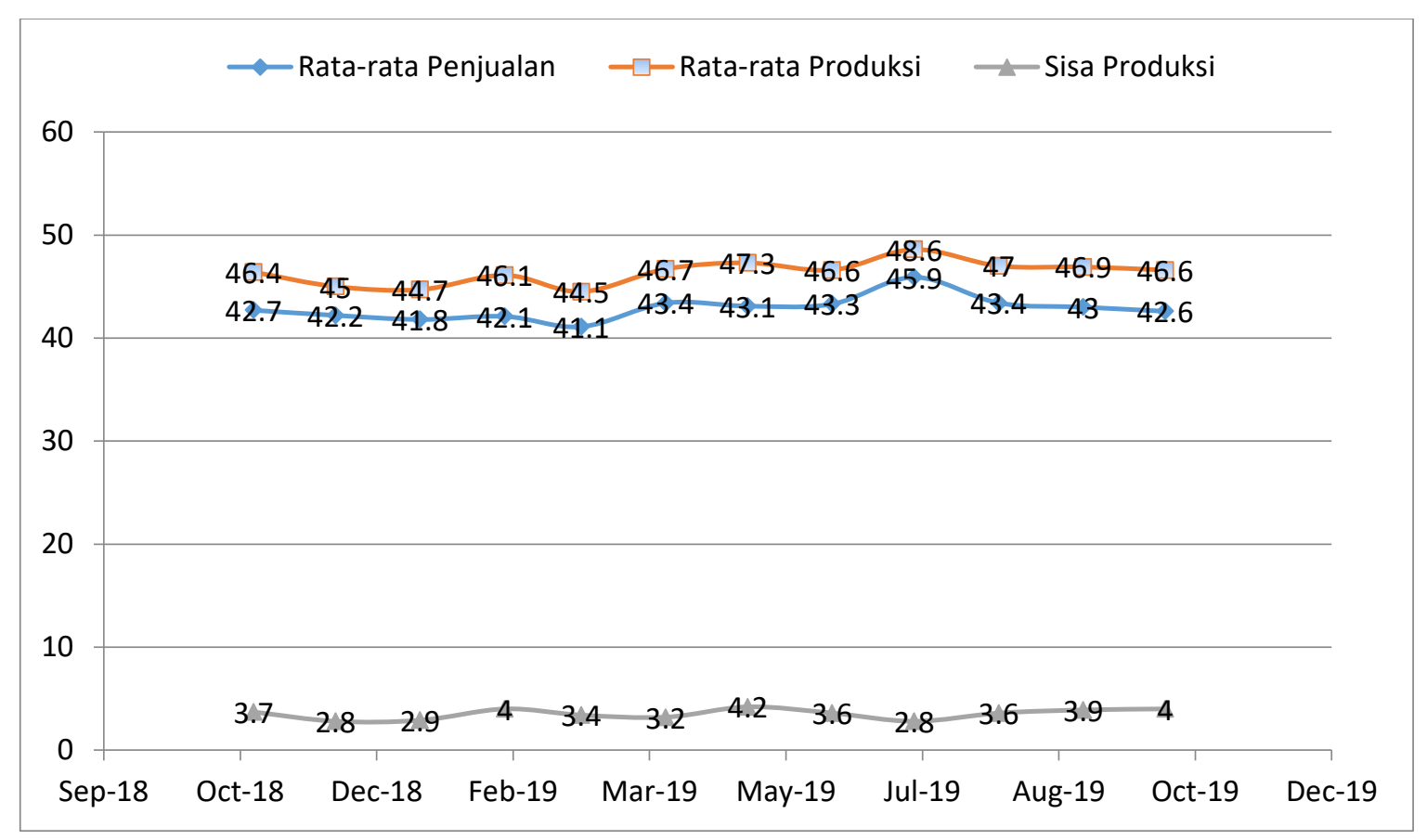

Gambar 2. Grafik Aktifitas Perdagangan Batik Fendy (lusin)

Berdasarkan Gambar 2 dapat diketahui rata-rata penjualan batik Fendy mengalami fluktuasi. Rata-rata penjualan batik tertinggi pada bulan Juli sebesar 45,9 lusin penjualan batik pada bulan ini meningkat karena adanya peningkatan permintaan seragam batik untuk seragam sekolah, dan juga instansi pemerintah dan penjualan rata-rata terendah pada bulan Maret yaitu 41,1 lusin hal ini terjadi karena pada bulan maret oleh karena banyak pesaing yang menjual produknya dengan harga murah dan lesunya perekonomian, tidak adanya momen peringatan dengan skala besar pada bulan tersebut. Rata-rata pembelian Batik Fendy pada bulan November tahun 2018 sampai Maret tahun 2019 mengalami penurunan. Namun pada bulan selanjutnya mengalami kenaikan yang cukup signifikan. Kenaikkan tersebut tidak bertahan lama, terbukti pada dua bulan setelahnya yaitu bulan Mei dan Juni mengalami penurunan. Baru pada bulan Juli mengalami peningkatan yang tajam dikarenakan bersamaan dengan momentum rutin setiap tahunnya. Adanya peningkatan permintaan akan seragam batik untuk pernikahan karena bisanya banyak pasangan yang menikah setelah lebaran, juga seragam sekolah untuk penerimaan siswa baru dan seragam untuk pilkada menjadi pemicunya. Namun setelah beberapa momentum besar tersebut selesai, rata-rata penjualan pun mengalami penurunan.

Rata-rata produksi batik di Batik Fendy selalu melebihi penjualan setiap bulannya. Rata-rata memproduksi antara 44 sampai 48 lusin setiap bulannya. Jumlah produksi rata-rata pada terendah pada bulan maret sebesar 44,5 lusin hal ini dikarenakan respon dari penjualan pada bulan-bulan sebelumnya. Selain itu bertepatan dengan adanya hari kemerdekaan banyak pesanan kain batik untuk dibuat seragam untuk berbagai event saat tujuh belasan. Dan begitu pula dengan rata-rata produksi tertinggi pada bulan agustus yaitu 48,6 lusin dikarenakan pada bulan sebelumnya mengalami puncak penjualan. Berdasarkan gambar 2 tersebut dapat diketahui rata-rata produksi Fendi batik setiap bulannya tidak menentu dan berfluktuatif. Dikarenakan selalu memproduksi lebih dari penjualan, maka setiap bulannya mengalami barang yang sisa. Rata-rata sisa produksi yang tidak terjual sebesar 2 sampai 4 lusin perbulannya. Rata-rata sisa produksi yang paling kecil pada bulan Desember dan bulan Agustus, sedangkan sisa produksi yang tidak terjual tertinggi 
pada bulan Mei yaitu 4,2 lusin. Sisa produksi batik Fendy pada setiap bulan cukup tinggi karena perhitungan untuk peramalan yang dilakukan belum terlalu baik dan akurat.

Tabel 2. Hasil perhitungan MAPE

\begin{tabular}{ll}
\multicolumn{1}{c}{ Varian } & $\begin{array}{c}\text { MAPE } \\
\text { (\%) }\end{array}$ \\
\hline Kemeja Cowok Lengan Pendek & 3.68 \\
Kemeja Cowok Lengan Pendek Furing & 5.85 \\
Kemeja Cowok Lengan Panjang & 5.79 \\
Kemeja Cowok Lengan Panjang Furing & 6.04 \\
Blus kombinasi lengan pendek & 6.27 \\
Blus kombinasi lengan pendek furing & 6.18 \\
Blus kombinasi lengan panjang & 6.02 \\
Blus kombinasi lengan panjang furing & 6.59 \\
Sarimbit lengan pendek & 10.37 \\
Sarimbit lengan pendek furing & 12.56 \\
Sarimbit lengan panjang & 17.50 \\
Sarimbit lengan panjang furing & 15.07 \\
\hline
\end{tabular}

Tabel 2 merupakan hasil perhitungan Tingkat keefektifan atau tingkat akurasi peramalan yang dilakukan oleh perusahaan Batik Fendy. Adapun nilai keakuratan peramalan dengan teknik MAPE adalah mendekati 0 (nol), yaitu semakin kecil nilai MAPE, maka semakin akurat peramalan yang dilakukan. Peramalan produksi digunakan untuk mengetahui jumlah produksi yang akan dilakukan sehingga jika jumlah produksi pada peramalan tersebut sama dengan jumlah penjualan atau dengan kata lain tidak bersisa maka dianggap akurat. Misalnya saja, pada tabel 2 dapat dilihat nilai MAPE paling kecil adalah pada varian Kemeja Cowok Lengan Pendek sebesar $3,68 \%$, sehingga dapat disimpulkan pada varian ini peramalan permintaan yang dilakukan oleh perusahaan Batik Fendy memiliki tingkat akurasi sebesar 96,32\% (penghitungan: 100\% - 3,68\%). Sedangkan hasil perhitungan MAPE paling besar adalah pada varian Sarimbit Lengan Panjang sebesar $17,5 \%$ yang berarti tingkat kesalahan peramalan permintaan yang dilakukan oleh perusahaan Batik Fendy adalah 17,5\% dengan tingkat akurasi sebesar 82,5\% (penghitungan: 100\% - 17,5\%). Setelah mengetahui nilai MAPE dengan nilai terkecil dan terbesar maka dapat untuk memperbaiki kesalahan dalam meramal khusus pada yang nilai MAPEnya besar perlu dipertimbangkan untuk jumlah yang harus diproduksi selanjutnya.

Pada tahap perhitungan MAPE dengan data penjualan dan data produksi Batik Fendy, ditemukan bahwa angka MAPE terbesar adalah pada varian sarimbit lengan Panjang. Sehingga peneliti menentukan peramalan permintaan dengan metode linear exponensial smoothing untuk data penjualan varian batik sarimbit lengan panjang periode November 2018 sampai oktober 2019. Berikut adalah hasil perhitungan peramalannya: 
Jurnal Ekonomi \& Pendidikan, 16(2), 2019

Tabel 3. Hasil Peramalan penjualan varian sarimbit lengan panjang batik Fendy

\begin{tabular}{lcccc}
\hline \multicolumn{1}{c}{ Bulan } & Data Aktual & $\mathbf{S}_{\mathbf{t}}$ & $\mathbf{T}_{\mathbf{t}}$ & $\mathbf{F}$ \\
\hline November 2018 & 216 & 216 & -12 & \\
Desember 2018 & 225 & 221 & -10 & 204 \\
Januari 2019 & 185 & 190 & -12 & 210 \\
Fabruari & 176 & 176 & -12 & 178 \\
Maret & 155 & 157 & -13 & 164 \\
April & 203 & 191 & -8 & 144 \\
Mei & 225 & 217 & -5 & 183 \\
Juni & 219 & 217 & -4 & 211 \\
Juli & 216 & 215 & -4 & 213 \\
Agustus & 223 & 221 & -3 & 211 \\
September & 215 & 215 & -3 & 217 \\
Oktober & 219 & 218 & -3 & 212 \\
November & $?$ & - & - & 215 \\
\hline
\end{tabular}

Berdasarkan hasil perhitungan pada tabel 3, pada kolom St merupakan unsur fluktuasi data, sedangkan kolom Tt merupakan unsur tren atau kecenderungan data, yang digunakan sebagai dasar melakukan prediksi untuk penjualan periode berikutnya sehingga pada bulan November 2019 dapat diprediksi penjualan batik Fendy untuk varian sarimbit lengan panjang adalah sebanyak 215 potong baju, atau sekitar 18 lusin.

Tabel 4. Pengukuran efektifitas peramalan exponential smoothing dengan teknik MAPE

\begin{tabular}{lccc}
\hline Bulan & Data Aktual & F & \% kesalahan peramalan \\
\hline November & 216 & & \\
Desember & 225 & 204 & 9.33 \\
Januari & 185 & 210 & 13.51 \\
Februari & 176 & 178 & 1.14 \\
Maret & 155 & 164 & 5.81 \\
April & 203 & 144 & 29.28 \\
Mei & 225 & 183 & 18.82 \\
Juni & 219 & 211 & 3.44 \\
Juli & 216 & 213 & 1.37 \\
Agustus & 223 & 211 & 5.30 \\
September & 215 & 217 & 0.93 \\
Oktober & 219 & 212 & 3.19 \\
November & $?$ & 215 & \\
MAPE & & & 9.21 \\
\hline
\end{tabular}

Pada tabel 4, dapat diketahui untuk varian batik sarimbit lengan panjang, prosentase kesalahan dalam memprediksi penjualan paling besar adalah pada bulan april 2019, yakni sebesar $29,28 \%$, sedangkan prosentase kesalahan peramalan terkecil terjadi pada bulan September, sebesar $0,93 \%$. Kesalahan dalam memprediksi ini disebabkan karena adanya fluktuasi data penjualan 
aktual. Dan secara keseluruhan dengan menggunakan teknik evaluasi Mean Absolute Precentage Error diperoleh rata-rata kesalahan peramalannya adalah 9,21\%.

Berdasarkan penelitian sebelumnya metode ini tidak hanya bisa untuk memprediksi jumlah produksi, tetapi dapat memprediksi jumlah wisatawan dengan akurat dengan rata-rata kesalahan lebih kecil yaitu 6,27\% dan 6,48\% (Kinasih, Agoestanto, \& Sugiman, 2018:37; Kusuma, Rifai, \& Sudirman, 2019:105). Sejalan dengan penelitian sebelumnya penelitian menngunakan metode yang sama untuk mencari nilai MAPE yang terkecil dengan metode exponential smoothing dan nilai MAPE menurut teori semakin mendekati nol nilainya lebih baik. Pada penelitian ini nilai MAPE adalah sebesar 9,21\% nilainya tergolong kecil masih dibawah 2 digit.

\section{SIMPULAN}

Berdasarkan hasil penelitian yang telah dilakukan, peneliti memperoleh kesimpulan, bahwa dengan menggunakan teknik evaluasi peramalan permintaan MAPE, dihasilkan metode peramalan Linear Exponential Smoothing lebih akurat dibandingkan dengan metode peramalan yang dilakukan oleh pengelola Batik Fendy, hal ini dapat dilihat dari hasil MAPE dengan metode peramalan Linear Exponential Smoothing sebesar 9,21\% lebih kecil dibandingkan dengan MAPE dari metode peramalan yang dilakukan pengelola Batik Fendy sebesar 17,5\%. Sehingga untuk memprediksi penjualan bulan November, Batik Fendy hendaknya memproduksi batik untuk varian sarimbit lengan panjang sebanyak 215 potong baju atau sekitar 18 lusin.

\section{DAFTAR PUSTAKA}

Heizer, Jay. Render, Barry. Munson, C. (2017). Operations management: sustainability and supply chain management. Journal of purchasing and supply management

Khamaludin, K. (2019). Peramalan Penjualan Hijab Sxproject Menggunakan Metode Moving Average Dan Exponential Smoothing. Unistek, 6(2), 13-16.

Kinasih, S., Agoestanto, A., \& Sugiman. (2018). Optimasi Parameter pada Model Exponential Smoothing Menggunakan Metode. UNNES Journal of Mathematics, 7(1), 37-46.

Kusuma, D. T., Rifai, M. F., \& Sudirman, M. Y. (2019). Penerapan Metode Triple Exponential Smoothing Pada Sistem Prediksi Keuntungan Bisnis Ayam Broiler Guna Meningkatkan Pengelolaan Keuangan Peternak. Kilat, 8(2), 103-111.

Land, K. C. (2015). Forecasting. In International Encyclopedia of the Social \& Behavioral Sciences: Second Edition. Elsevier Science \& Technology.

Maricar, M. A. (2019). Analisa Perbandingan Nilai Akurasi Moving Average dan Exponential Smoothing untuk Sistem Peramalan Pendapatan pada Perusahaan XYZ. Jurnal Sistem dan Informatika,13(2), 36-45.

Rachman, R. (2018). Penerapan Metode Moving Average Dan Exponential Smoothing Pada Peramalan Produksi Industri Garment. Jurnal Informatika, 5(2), 211-220.

Taylor, S. J., \& Letham, B. (2018). Forecasting at Scale. The American Statistician, 72(1), 37-45.

Yuniastari, N. L. A. K., \& Wirawan, I. W. W. (2016). Peramalan Permintaan Produk Perak Menggunakan Metode Simple Moving Average Dan Single Exponential Smoothing. Sistem Dan Informatika STIKOM Bali, 97-106.

Yunika, S., \& Sugiono. (2017). Sistem Peramalan Menggunakan Metode Exponential Smoothing Dan Weight Moving Average Di Perusahaan Konstruksi Telekomunikasi. Konvergensi, 13(2), 59-67 